\title{
Tofu processing wastewater as a low-cost substrate for high activity nattokinase production using Bacillus subtilis
}

\author{
Tao Li ${ }^{\dagger}$, Chenyi Zhan ${ }^{\dagger}$, Gege Guo, Zhaoxing Liu, Ning Hao* and Pingkai Ouyang
}

\begin{abstract}
Background: Even though tofu is a traditional Chinese food loved by Asian people the wastewater generated during the production of tofu can pollute the environment, and the treatment of this generated wastewater can increase the operating cost of the plant. In this study, the production of nattokinase could be achieved by using the nitrogen source in tofu processing wastewater (TPW) instead of using the traditional nattokinase medium. This meets the need for the low-cost fermentation of nattokinase and at the same time addresses the environmental pollution concerns caused by the wastewater. Bacillus subtilis 13,932 is, a high yielding strain of nattokinase, which is stored in our laboratory. To increase the activity of nattokinase in the tofu process wastewater fermentation medium, the medium components and culture parameters were optimized. Nattokinase with high enzymatic activity was obtained in $7 \mathrm{~L}$ and $100 \mathrm{~L}$ bioreactors when TPW was used as the sole nitrogen source catalyzed by Bacillus subtilis. Such a result demonstrates that the production of nattokinase from TPW fermentation using B. subtilis can be implemented at an industrial level.

Results: The peptide component in TPW is a crucial factor in the production of nattokinase. Box-Behnken design (BBD) experiments were designed to optimize various critical components, i.e., Glucose, $\mathrm{TPW}, \mathrm{MgSO}_{4} \cdot 7 \mathrm{H}_{2} \mathrm{O}, \mathrm{CaCl}_{2}$, in nattokinase fermentation media. A maximum nattokinase activity was recorded at $37^{\circ} \mathrm{C}, \mathrm{pH} 7.0,70 \mathrm{~mL}$ liquid medium, and $200 \mathrm{rpm}$. The highest nattokinase activities obtained from 7 to $100 \mathrm{~L}$ bioreactors were $8628.35 \pm 113.87 \mathrm{IU} / \mathrm{mL}$ and 10,661.97 $\pm 72.47 \mathrm{IU} / \mathrm{mL}$, respectively.

Conclusions: By replacing the nitrogen source in the original medium with TPW, there was an increase in the enzyme activity by $19.25 \%$ after optimizing the medium and culture parameters. According to the scale-up experiment from conical flasks to $100 \mathrm{~L}$ bioreactors, there was an increase in the activity of nattokinase by $47.89 \%$.
\end{abstract}

Keywords: Tofu processing wastewater, Bacillus subtilis, Nattokinase, Media optimization

*Correspondence: haoning@njtech.edu.cn

${ }^{\dagger}$ Tao Li and Chenyi Zhan have contributed equally to this work College of Biotechnology and Pharmaceutical Engineering, State Key Laboratory of Materials-Oriented Chemical Engineering, Jiangsu National Synergetic Innovation Center for Advanced Materials (SICAM), Nanjing Tech University, Nanjing 211816, China

\section{Background}

Being a serine proteinase, nattokinase has been widely used in the prevention and treatment of thrombosisrelated disease due to its strong fibrin hydrolysis ability $[1,2]$. Compared with urokinase and streptokinase, nattokinase is safer, more economical and it can be more easily absorbed by the body [3]. According to a recent survey, nearly 17 million people die each year from cardiovascular-related diseases [4]. As such, to address this critical issue, nattokinase has been extensively researched 
for its potential in treating these diseases. Nattokinase has presented a significant impact in the Chinese culture as a functional food or as an intravenous drug. Thus, to meet the market demand for nattokinase, it is highly vital to reduce the cost of nattokinase fermentation media and to increase the yield of nattokinase during production.

Currently, various low-cost raw material have been explored for the fermentation production of nattokinase [5, 6]. For instance, Ansuman Sahoo et al. [7] had reported the use of cheese whey as an alternative raw material for the production of nattokinase. It was shown that the nattokinase activity increased to $833.43 \mathrm{U} /$ $\mathrm{mL}$ after being supplied with $10 \mathrm{~g} / \mathrm{L}$ yeast extract, while achieving a corresponding reduction in the cost of the fermentation medium by 55-56\%. Pan et al. [8] used cassava starch and soybean as their carbon and nitrogen sources for the production of the fibrinolytic enzyme. The fermentation process in a $100 \mathrm{~L}$ pilot fermenter was optimized, and a maximum fibrinolytic enzyme activity of $3787 \mathrm{U} / \mathrm{mL}$ was achieved. The fermentation of soybean residue as a component of the medium for the co-production of nattokinase and MK-7 was reported by Wang et al. [9]. It was shown that after the optimization of the response surface, the concentrations of MK-7 and nattokinase were able to reach $91.25 \mathrm{mg} / \mathrm{L}$ and $2675.73 \mathrm{U} /$ $\mathrm{mL}$, respectively. Thus, it can be concluded that the use of low-cost raw materials as substrates is a common and effective strategy in achieving an economical nattokinase fermentation.

Tofu processing wastewater (TPW) is a major byproduct generated during the tofu preparation process, whereby approximately 7-10 kg of wastewater is produced per $1 \mathrm{~kg}$ of soybeans processed $[10,11]$. Due to the high chemical oxygen demand (COD) and biochemical oxygen demand (BOD) content in TPW, it cannot be discharged directly into the environment $[12,13]$. The nutrient-rich wastewater generated from tofu processing contains about $0.59 \mathrm{~g} / \mathrm{L}$ total nitrogen, $0.078 \mathrm{~g} / \mathrm{L}$ ammonia nitrogen, $0.26 \mathrm{~g} / \mathrm{L}$ nitrate, and various metal ions, which provide suitable environments for the microorganisms to grow [14]. Hence, to reduce the risk of causing damage to the environment and humans, it is vital for the soy processing industry to recycle and treat TPW, even though this may result in increased production costs. In this study, nitrogen source in the original medium was replaced with wastewater generated from tofu processing. Based on this concept, Box-Behnken design (BBD) experiments were designed to optimize the content of each component in the medium. In addition to the optimization of components in the medium, environmental parameters were also optimized appropriately. To demonstrate the scalability of the as-proposed strategy in industrial-level wastewater utilization, the output of the nattokinase fermentation was scaled up from shake flask to $100 \mathrm{~L}$ bioreactor. The trend of the enzyme production from Bacillus subtilis fermentation under different conditions was also investigated.

\section{Results}

\section{Comparison of different nitrogen sources on nattokinase activity and biomass}

Soy peptone was added to the basal fermentation medium at a concentration of $25 \mathrm{~g} / \mathrm{L}$ (about $9 \%$ of total nitrogen), while other organic and inorganic nitrogen were added with the same total nitrogen content of $2.25 \mathrm{~g} / \mathrm{L}$. The effects of TPW on the fermentative activity of nattokinase were compared with those of five other nitrogen sources, and the results are shown in Fig. 1. The highest nattokinase activity of $6045.58 \pm 69.62 \mathrm{IU} /$ $\mathrm{mL}$ was produced by TPW, which is far superior as compared to the results obtained from other sources. This is then followed by the enzyme activities produced by soy peptone, yeast powder, and corn pulp, whereby increased enzyme activities of $5429.25 \pm 101.66 \mathrm{IU} / \mathrm{mL}$, $4525.32 \pm 133.207 \mathrm{IU} / \mathrm{mL}$, and $3207.16 \pm 87.05 \mathrm{IU} / \mathrm{mL}$, respectively, are achieved.

In contrast, two inorganic nitrogen sources, i.e., $\left(\mathrm{NH}_{4}\right)_{2} \mathrm{SO}_{4}$ and urea, are ineffective in the synthesis of nattokinase, as the nattokinase activities are less than $2000 \mathrm{IU} / \mathrm{mL}$ (Fig. 1).

\section{Effects of different amino acids and peptides on the fermentation of nattokinase}

The main nitrogen source components in TPW that are used for the growth of Bacillus subtilis include proteins, amino acids, peptides, etc. These components

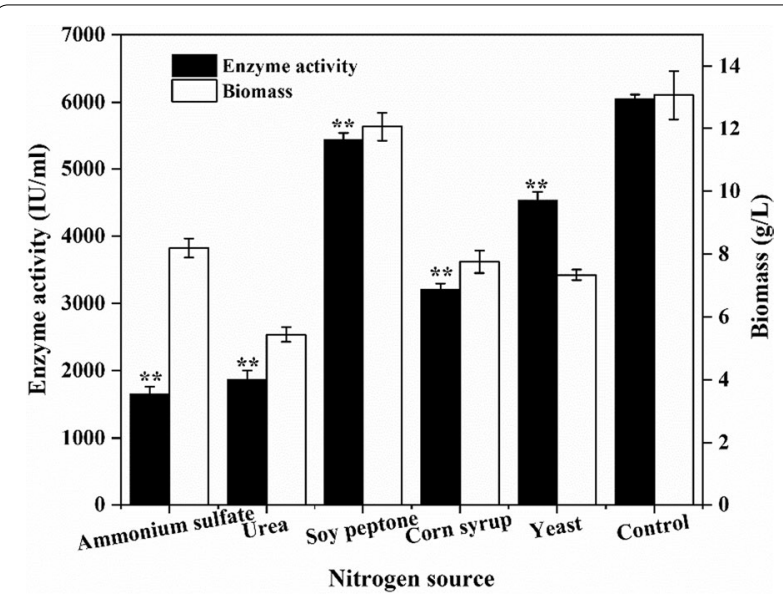

Fig. 1 Comparison of the effects of different nitrogen sources on the synthesis of nattokinase. Control: 100\% TPW as nitrogen source for blank control. *Significance code: $P<0.05$; **Significance code: $P<0.01$. 
may induce an increase in the expression of nattokinase. As such, the primary amino acid components in TPW were determined using high-performance liquid chromatography (HPLC), and the results are shown in Table 1. It is revealed that TPW mainly contains eight amino acids, i.e., Asp, Glu, Arg, Ser, Gly, Leu, Lys, and His, with Asp, Glu, and Arg (>1000 mg/L) having the highest concentrations; Ser and Gly $(>100 \mathrm{mg} / \mathrm{L}$, $<1000 \mathrm{mg} / \mathrm{L}$ ) having the second-highest concentrations; and the remaining amino acid fractions having lower concentrations $(<100 \mathrm{mg} / \mathrm{L})$. Subsequently, to observe the effects of amino acid compositions on the fermentation of nattokinase, different types of amino acids were added to the control medium. As shown in Fig. 2a, the addition of Leu, Asp, Gly, and Arg at low concentrations of $0.2 \%$ can significantly increase the nattokinase activity. However, such an effect diminishes as the concentration of amino acid increases. Only Leu exhibit a more pronounced enhancement in the enzyme activity. In contrast, increasing the concentration of glutamate can increase the inhibition of nattokinase synthesis, which indicates that glutamate can exert a significant inhibitory effect on the fermentation of nattokinase. Figure $2 \mathrm{~b}$ shows the significant effects of supernatant 1 and supernatant 2 on increasing the nattokinase activity. When compared with the control group, the activity of nattokinase after adding supernatant 1 and 2 increase by $89.99 \%$ and $49.53 \%$, respectively. However, adding soymilk to the system shows a negligible effect on the increase in enzyme activity.

\section{Optimization of nattokinase production using BBD}

Based on the relevant literature and previous experimental results, various compounds such as glucose, TPW, $\mathrm{MgSO}_{4} \cdot 7 \mathrm{H}_{2} \mathrm{O}$, and $\mathrm{CaCl}_{2}$ had been confirmed to exert significant effects on enhancing the nattokinase activity. As such, to enhance the nattokinase activity, the fermentation medium was optimized by designing a 3-level BBD experiment based on 4-factor. Twentynine sets of experiments (with each repeated three times) were designed using BBD, and the results were validated using the actual and predicted values as summarized in Table 2. The results shown in Table 2 were analyzed with linear regression using Design Expert11 software, and the quadratic polynomial regression equation obtained by standard ANOVA was;

Table 1 Amino acid contents in each component

\begin{tabular}{lrrrrrrrr}
\hline & Asp/mg/L & \multicolumn{1}{c}{ Ser/mg/L } & \multicolumn{1}{c}{ Gly/mg/L } & Arg/mg/L & \multicolumn{1}{c}{ Lys/mg/L } & Glu/mg/L & His/mg/L & Leu/mg/L \\
\hline Supernatant 1 & $36.12 \pm 1.05$ & $62.75 \pm 2.83$ & $22.01 \pm 2.16$ & $21.8 \pm 1.21$ & $15.55 \pm 0.45$ & $1072.88 \pm 25.38$ & $2670.45 \pm 9.07$ & $5.39 \pm 0.79$ \\
Supernatant 2 & $15.34 \pm 0.59$ & $21.13 \pm 1.80$ & $8.63 \pm 0.60$ & $9.25 \pm 0.88$ & $4.71 \pm 0.55$ & $1061.16 \pm 3.67$ & $4044.52 \pm 29.28$ & $71.15 \pm 1.55$ \\
TPW & $2001.60 \pm 5.09$ & $955.23 \pm 5.51$ & $601.74 \pm 3.28$ & $601.90 \pm 3.46$ & $83.09 \pm 2.66$ & $1875.47 \pm 19.78$ & $124.59 \pm 8.29$ & $10.34 \pm 1.06$ \\
\hline
\end{tabular}
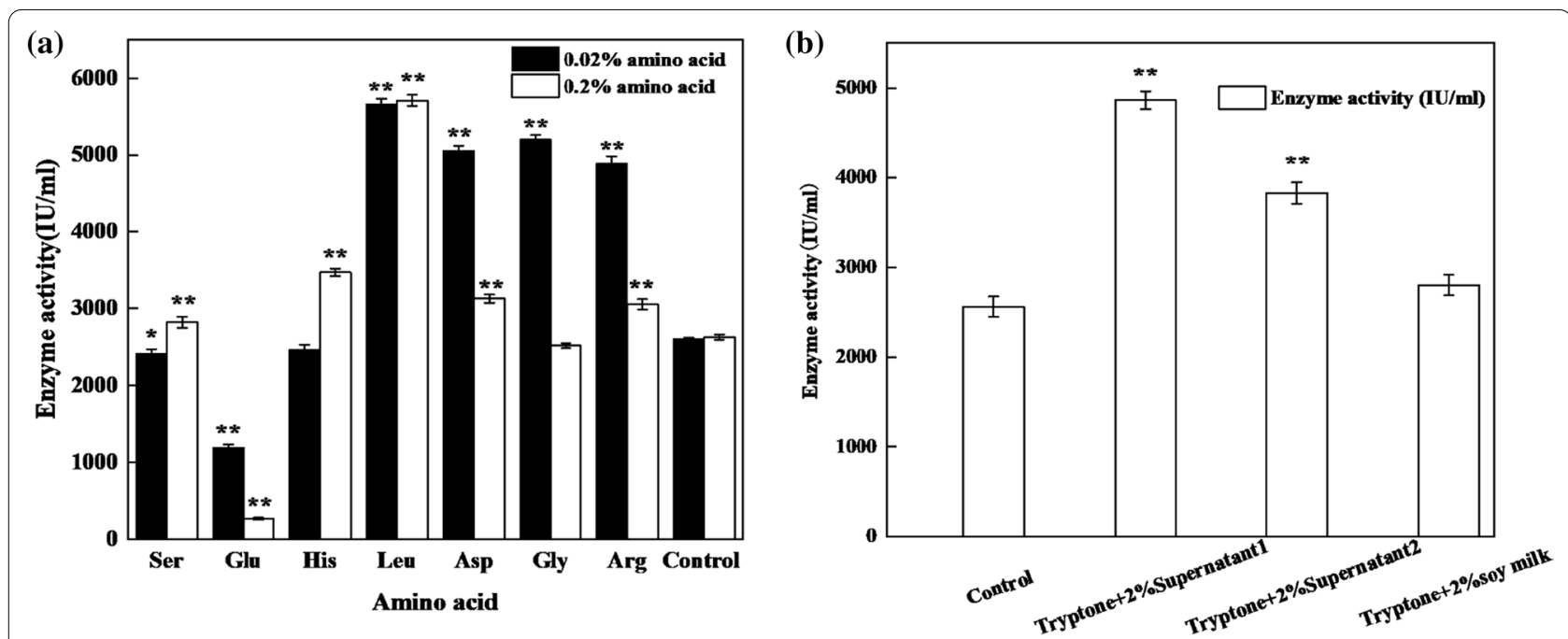

Fig. 2 Effects of various amino acids (a) and soy milk hydrolysate (b) on the nattokinase activity. Control: $20 \mathrm{~g} / \mathrm{L}$ Tryptone as nitrogen source for blank control. *Significance code: $P<0.05 ;{ }^{*}$ Significance code: $P<0.01$. 
Table 2 Experimental design and results of the Box-Behnken Design

\begin{tabular}{|c|c|c|c|c|c|c|}
\hline \multirow[b]{2}{*}{ Run } & \multirow{2}{*}{$\begin{array}{l}\text { Factor } 1 \\
\text { A: Glucose (g/L) }\end{array}$} & \multirow{2}{*}{$\begin{array}{l}\text { Factor } 2 \\
\text { B:TPW (\%) }\end{array}$} & \multirow{2}{*}{$\begin{array}{l}\text { Factor } 3 \\
\mathrm{C:} \mathrm{MgSO}_{4} \cdot 7 \mathrm{H}_{2} \mathrm{O} \\
(\mathrm{g} / \mathrm{L})\end{array}$} & \multirow{2}{*}{$\begin{array}{l}\text { Factor } 4 \\
\mathrm{D}: \mathrm{CaCl}_{2}(\mathrm{~g} / \mathrm{L})\end{array}$} & \multicolumn{2}{|c|}{ Enzyme activity (IU/mL) } \\
\hline & & & & & Actual value & Predicted value \\
\hline 1 & 22.5 & 100 & 1 & 1 & $7472.70 \pm 137.28$ & 7549.40 \\
\hline 2 & 22.5 & 75 & 0.5 & 0.1 & $6863.40 \pm 84.29$ & 6484.19 \\
\hline 3 & 22.5 & 100 & 0.5 & 0.55 & $7719.21 \pm 69.39$ & 7763.18 \\
\hline 4 & 35 & 75 & 1 & 1 & $4637.23 \pm 32.82$ & 5219.90 \\
\hline 5 & 10 & 75 & 0.5 & 0.55 & $5608.72 \pm 118.44$ & 5867.68 \\
\hline 6 & 22.5 & 75 & 1 & 0.55 & $7202.28 \pm 72.56$ & 7045.27 \\
\hline 7 & 22.5 & 50 & 1 & 1 & $2552.45 \pm 40.53$ & 2729.88 \\
\hline 8 & 22.5 & 75 & 0.5 & 1 & $6631.05 \pm 31.61$ & 6298.53 \\
\hline 9 & 22.5 & 100 & 1.5 & 0.55 & $7563.01 \pm 50.01$ & 7541.37 \\
\hline 10 & 22.5 & 75 & 1 & 0.55 & $7306.88 \pm 48.21$ & 7045.27 \\
\hline 11 & 22.5 & 50 & 1.5 & 0.55 & $2685.39 \pm 156.66$ & 2746.88 \\
\hline 12 & 35 & 75 & 1.5 & 0.55 & $4927.65 \pm 94.96$ & 4905.82 \\
\hline 13 & 22.5 & 75 & 1.5 & 1 & $6627.17 \pm 75.44$ & 6663.81 \\
\hline 14 & 22.5 & 75 & 1 & 0.55 & $7163.78 \pm 46.64$ & 7045.27 \\
\hline 15 & 35 & 100 & 1 & 0.55 & $6522.90 \pm 55.96$ & 5870.37 \\
\hline 16 & 22.5 & 75 & 1 & 0.55 & $6900.12 \pm 49.35$ & 7045.27 \\
\hline 17 & 10 & 75 & 1 & 1 & $5680.77 \pm 71.76$ & 5139.86 \\
\hline 18 & 10 & 75 & 1.5 & 0.55 & $5507.49 \pm 66.73$ & 5462.89 \\
\hline 19 & 10 & 50 & 1 & 0.55 & $1505.96 \pm 69.34$ & 1815.91 \\
\hline 20 & 22.5 & 50 & 0.5 & 0.55 & $2586.87 \pm 60.69$ & 2713.96 \\
\hline 21 & 10 & 100 & 1 & 0.55 & $6337.79 \pm 52.37$ & 6831.60 \\
\hline 22 & 22.5 & 75 & 1 & 0.55 & $6653.31 \pm 42.06$ & 7045.27 \\
\hline 23 & 35 & 50 & 1 & 0.55 & $1878.74 \pm 55.13$ & 1042.35 \\
\hline 24 & 35 & 75 & 0.5 & 0.55 & $4408.22 \pm 78.25$ & 4689.94 \\
\hline 25 & 22.5 & 75 & 1.5 & 0.1 & $5940.07 \pm 78.91$ & 5930.00 \\
\hline 26 & 10 & 75 & 1 & 0.1 & $6290.44 \pm 87.9$ & 5813.23 \\
\hline 27 & 22.5 & 50 & 1 & 0.1 & $2193.04 \pm 137.11$ & 2353.47 \\
\hline 28 & 22.5 & 100 & 1 & 0.1 & $7317.97 \pm 126.32$ & 7377.67 \\
\hline 29 & 35 & 75 & 1 & 0.1 & $3352.02 \pm 175.91$ & 3998.39 \\
\hline
\end{tabular}

$$
\begin{aligned}
& 7045.27-433.70 \mathrm{~A}+2460.93 \mathrm{~B}-47.23 \mathrm{C}+137.04 \mathrm{D} \\
& -46.92 \mathrm{AB}+155.16 \mathrm{AC}+473.72 \mathrm{AD}-63.68 \mathrm{BC} \\
& -51.17 \mathrm{BD}+229.87 \mathrm{CD}-1557.49 \mathrm{~A}^{2}-1597.73 \mathrm{~B}^{2} \\
& -256.20 \mathrm{C}^{2}-444.94 \mathrm{D}^{2} .
\end{aligned}
$$

According to the ANOVA results presented in Table 3, the model used is statistically significant as the model significance test $P$ value is less than 0.05 , while the $P$ value of the misfit term is 0.0775 (which is insignificant since it is more than 0.05). Figure 3 shows the relationships between the variables using 3D response surface plots. Based on Table 3, nattokinase fermentation is significantly affected by glucose $(0.0096<0.05)$ and TPW $(<0.0001)$. However, according to the $3 \mathrm{D}$ response surface plots (Fig. 3), no obvious relationship between the variables can be observed. It is worth noting that nattokinase activity decreases with decreasing TPW concentration, which indicates the vital role of TPW in achieving nattokinase with high enzymatic activity. It can be observed that the 3D response surface plots for all three variables are convex, except for TPW. At this point, there is an increase in the nattokinase activity with increasing concentrations of $\mathrm{TPW}, \mathrm{MgSO}_{4} \cdot 7 \mathrm{H}_{2} \mathrm{O}$, and $\mathrm{CaCl}_{2}$ until a maximum nattokinase activity is achieved. After which, there is a decrease in the enzyme activity with increasing concentrations of each variable. The experimental validation of nattokinase activity based on the optimal combination of fermentation media is slightly higher than that of the predicted value $(7092.5 \mathrm{IU} / \mathrm{mL})$, which suggests the reliability of the model. Thus, based on the results, the optimal medium combination consists of $30.868 \mathrm{~g} / \mathrm{L}$ glucose, 93.669\% TPW, $1.129 \mathrm{~g} / \mathrm{L} \mathrm{MgSO}_{4} \cdot 7 \mathrm{H}_{2} \mathrm{O}$, and $0.791 \mathrm{~g} / \mathrm{L} \mathrm{CaCl}_{2}$. 
Table 3 ANOVA result based on a quadratic model for the activity of nattokinase produced by Bacillus subtilis 13932

\begin{tabular}{|c|c|c|c|c|c|c|}
\hline Source & Sum of Squares & df & Mean Square & F-value & $P$ value & \\
\hline Model & $1.040 \mathrm{E}+08$ & 14 & $7.429 E+06$ & 29.56 & $<0.0001$ & Significant \\
\hline A-Glucose* & $2.257 E+06$ & 1 & $2.257 E+06$ & 8.98 & 0.0096 & \\
\hline B-TPW* & $7.267 E+07$ & 1 & $7.267 E+07$ & 289.17 & $<0.0001$ & \\
\hline $\mathrm{C}-\mathrm{MgSO}_{4}$ & $26,763.25$ & 1 & $26,763.25$ & 0.1065 & 0.7490 & \\
\hline $\mathrm{D}-\mathrm{CaCl}_{2}$ & $2.253 \mathrm{E}+05$ & 1 & $2.253 E+05$ & 0.8967 & 0.3597 & \\
\hline$A B$ & 8804.90 & 1 & 8804.90 & 0.0350 & 0.8542 & \\
\hline$A C$ & $96,304.36$ & 1 & $96,304.36$ & 0.3832 & 0.5458 & \\
\hline$A D$ & $8.976 E+05$ & 1 & $8.976 \mathrm{E}+05$ & 3.57 & 0.0797 & \\
\hline$B C$ & $16,221.98$ & 1 & $16,221.98$ & 0.0645 & 0.8031 & \\
\hline $\mathrm{BD}$ & $10,473.36$ & 1 & $10,473.36$ & 0.0417 & 0.8412 & \\
\hline$C D$ & $2.114 E+05$ & 1 & $2.114 \mathrm{E}+05$ & 0.8410 & 0.3746 & \\
\hline$A^{2 *}$ & $1.573 \mathrm{E}+07$ & 1 & $1.573 \mathrm{E}+07$ & 62.61 & $<0.0001$ & \\
\hline$B^{2 *}$ & $1.656 \mathrm{E}+07$ & 1 & $1.656 \mathrm{E}+07$ & 65.89 & $<0.0001$ & \\
\hline$C^{2}$ & $4.258 E+05$ & 1 & $4.258 \mathrm{E}+05$ & 1.69 & 0.2141 & \\
\hline$D^{2}$ & $1.284 E+06$ & 1 & $1.284 \mathrm{E}+06$ & 5.11 & 0.0403 & \\
\hline Residual & $3.518 \mathrm{E}+06$ & 14 & $2.513 E+05$ & & & \\
\hline Lack of Fit & $3.237 E+06$ & 10 & $3.237 E+05$ & 4.59 & 0.0775 & Not significant \\
\hline Pure Error & $2.818 \mathrm{E}+05$ & 4 & $70,460.26$ & & & \\
\hline Cor Total & $1.075 E+08$ & 28 & & & & \\
\hline
\end{tabular}

" Significant at $P<0.01$

\section{Optimization of fermentation conditions for the production of nattokinase}

Figure $4 \mathrm{a}$ illustrates the effects of initial $\mathrm{pH}$, i.e., from 5 to 8 , on the nattokinase activity of strain Bacillus subtilis 13932. According to the result, the highest enzyme activity $(6900.04 \pm 40.05 \mathrm{IU} / \mathrm{mL})$ and the highest biomass $(10.63 \pm 0.12 \mathrm{~g} / \mathrm{L})$ were obtained at the $\mathrm{pH}$ range of $7-7.5$. Meanwhile, varying degrees of reduction in the enzyme activity and biomass were observed at other $\mathrm{pH}$ values. Figure $4 \mathrm{~b}$ shows the amount of nattokinase produced by the strain Bacillus subtilis 13932 at pH 7 with different shaking speeds, i.e., 80, 120, 160, 200, and $240 \mathrm{rpm}$. Based on the result, the nattokinase activity and the bacterial biomass were significantly enhanced with increasing shaking speeds, whereby the highest nattokinase activity of $7167.42 \pm 49.59 \mathrm{IU} / \mathrm{mL}$ was achieved at $200 \mathrm{rpm}$. However, with increasing shaking speed beyond $200 \mathrm{rpm}$, the nattokinase activity was reduced to $3579.01 \pm 44.17 \mathrm{IU} /$ $\mathrm{mL}$. To evaluate the nattokinase activity at various medium volumes, the bacterial biomass of Bacillus subtilis and nattokinase activity were measured at medium volumes of $30 / 500 \mathrm{~mL}, 70 / 500 \mathrm{~mL}, 100 / 500 \mathrm{~mL}$, $130 / 500 \mathrm{~mL}$, and 160/500 mL. As shown in Fig. 4c, an optimal nattokinase activity of $7233.35 \pm 140.90$ IU/ $\mathrm{mL}$ was obtained at a medium volume of $70 \mathrm{~mL}$. Interestingly, as the medium volume increased from 70 to $160 \mathrm{~mL}$, there was a constant reduction in the nattokinase activity. Figure $4 \mathrm{~d}$ shows the gradual increase in the bacterial biomass and enzyme activity with increasing temperatures (when the fermentation temperature was in the range of $29-37^{\circ} \mathrm{C}$ ). As the temperature increased beyond $37{ }^{\circ} \mathrm{C}$, both the enzyme production and dry weight of bacteria exhibited further reduction. Thus, based on the collective results, it can be concluded that $37{ }^{\circ} \mathrm{C}$ is the optimal temperature for the growth of Bacillus subtilis $(8.24 \pm 0.09 \mathrm{~g} / \mathrm{L})$ and enzyme production $(6984.51 \pm 26.25 \mathrm{IU} / \mathrm{mL})$.

\section{Cost and scaling up of batch fermentation}

It has been shown through the optimization experiments (based on shake flask set-up) that Bacillus subtilis 13,932 can ferment TPW to produce nattokinase with high enzymatic activity. To demonstrate the scalability and reliability of the fermentation process, scale-up experiments involving $7 \mathrm{~L}$ and $100 \mathrm{~L}$ bioreactors were conducted, and the results are shown in Fig. 5a and b, respectively. The highest nattokinase activity of $8628.365 \pm 113.87 \mathrm{IU} / \mathrm{mL}$ is achieved in the $7 \mathrm{~L}$ bioreactor after $20 \mathrm{~h}$. In contrast, the maximum nattokinase activity in the $100 \mathrm{~L}$ bioreactor is achieved after only $10 \mathrm{~h}$, and there is a $23.56 \%$ increase in the nattokinase activity as compared to that recorded in the $7 \mathrm{~L}$ bioreactor. There is a rapid consumption of glucose during the fermentation process, with almost fully depleted residual sugar contents in both bioreactors after $10-12 \mathrm{~h}$. It can be observed that the 


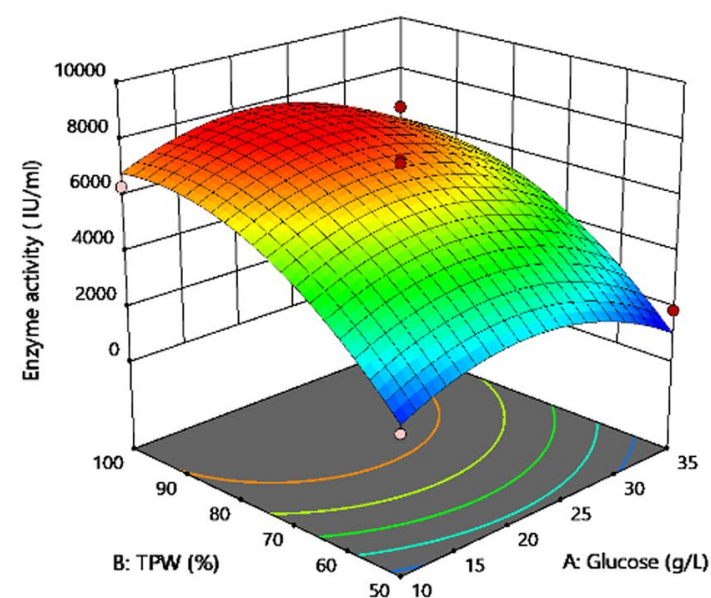

(a)

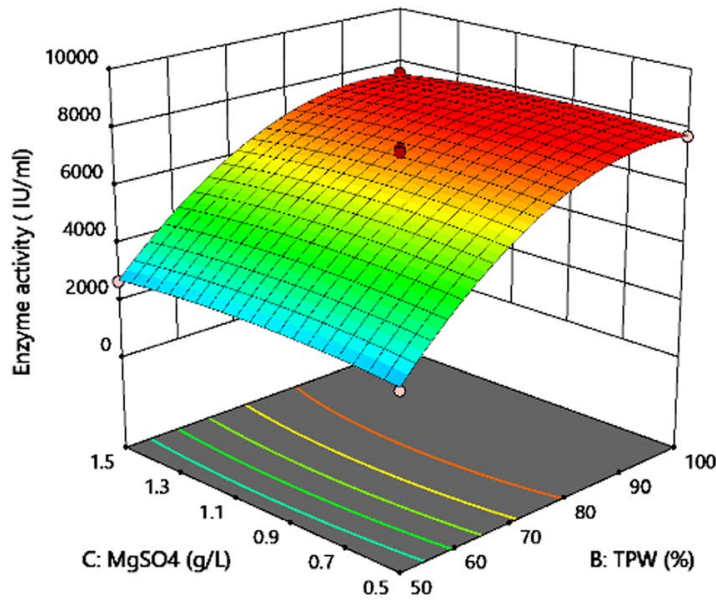

(c)

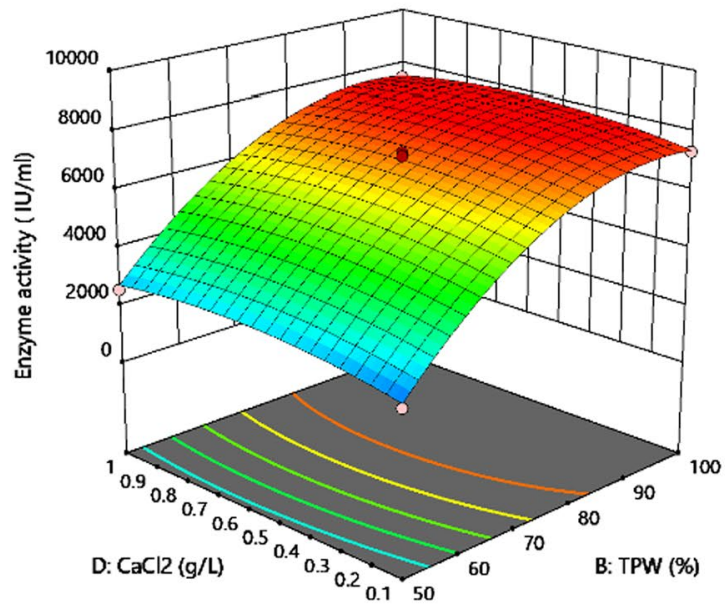

(e)

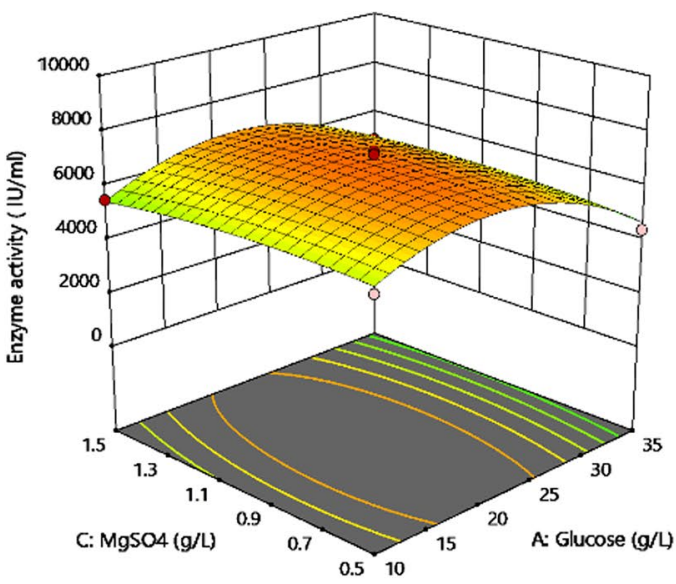

(b)

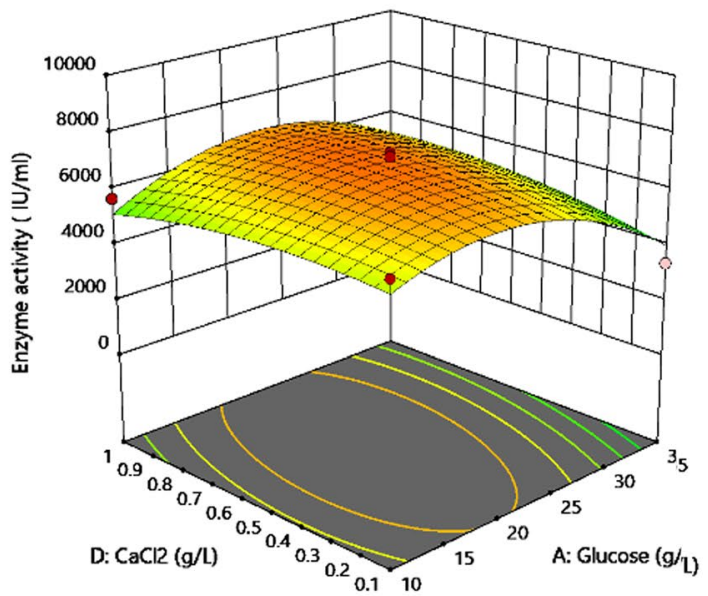

(d)

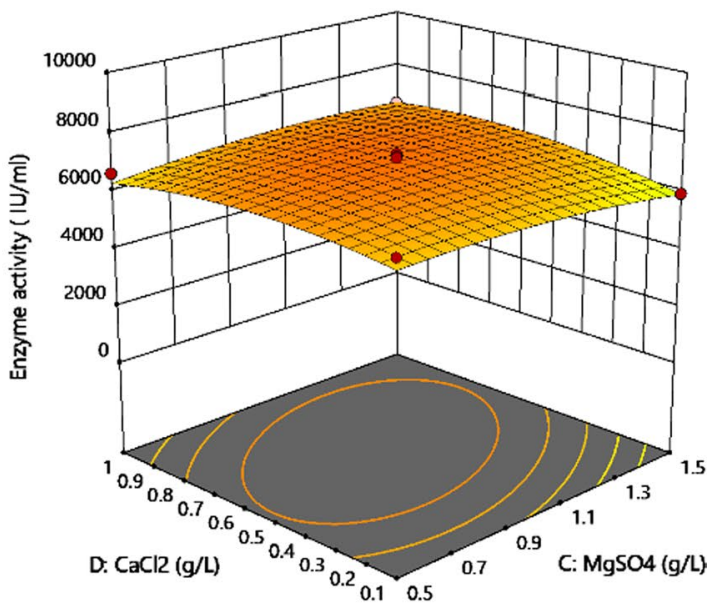

(f)

Fig. 3 Response surface curves showing the effects of each component in the medium on the production of nattokinase. The response curves show the interaction between different factors. a Interaction between TPW and glucose; $\mathbf{b}$ Interaction between $\mathrm{MgSO}_{4}$ and glucose; $\mathbf{c}$ Interaction between $\mathrm{MgSO}_{4}$ and TPW; $\mathbf{d}$ Interaction between $\mathrm{CaCl}_{2}$ and glucose; e Interaction between $\mathrm{CaCl}_{2}$ and TPW; $\mathbf{f}$ Interaction between $\mathrm{MgSO}_{4}$ and $\mathrm{CaCl}_{2}$ 

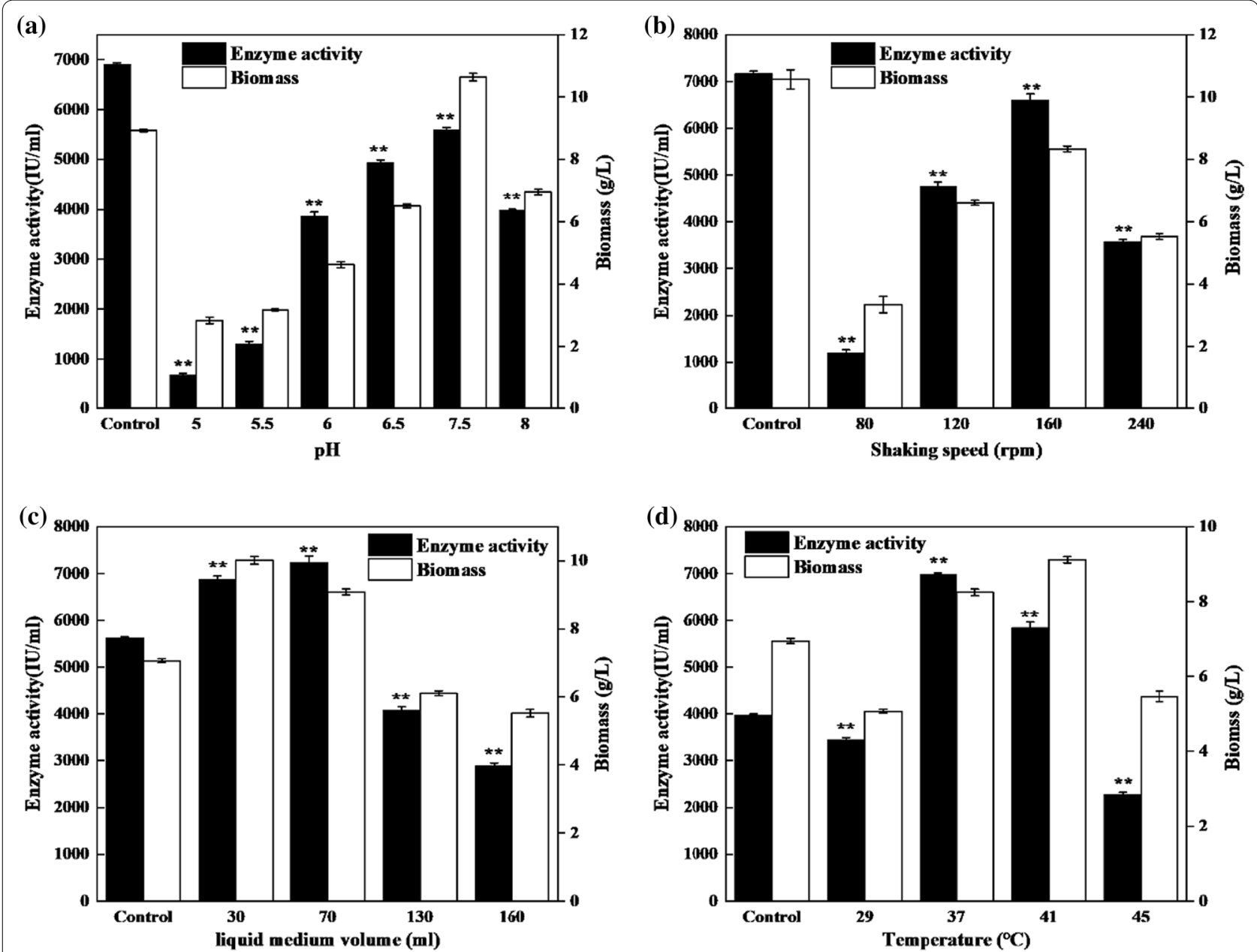

Fig. 4 Effects of initial pH (a), shaking speed (b), liquid medium volume (c), and temperature (d) on nattokinase activity. a Control: pH 7, b Control: shaking speed $200 \mathrm{rpm}$, c Control: liquid medium volume $100 \mathrm{~mL} / 500 \mathrm{~mL}$, d Control: temperature $33^{\circ} \mathrm{C}$. ${ }^{*}$ Significance code: $P<0.05 ;{ }^{* *}$ Significance code: $P<0.01$

biomass gradually reaches a maximum as the glucose is depleted. In the $7 \mathrm{~L}$ bioreactor, the biomass after $24 \mathrm{~h}$ reaches a maximum of $15.32 \pm 0.24 \mathrm{~g} / \mathrm{L}$. As the fermentation system is expanded to $100 \mathrm{~L}$, the maximum biomass of the bacteria reaches a maximum of $12.33 \pm 0.29 \mathrm{~g} / \mathrm{L}$ after $10 \mathrm{~h}$. Table 4 compares the cost of the nattokinase fermentation media and their corresponding maximum nattokinase activities from various literature. According to Table 4, higher nattokinase activity is obtained by replacing the nitrogen source in the original medium with TPW, when compared to other comparable literature. Furthermore, the cost of the as-proposed fermentation medium based on TPW is as low as US\$19, whereas the costs of other nattokinase fermentation media reported in the literature were at least US\$20.

\section{Discussion}

Nattokinase is produced during the fermentation of Bacillus subtilis, and it possesses good fibrinolysis property [15]. In this study, TPW was used as an alternative raw fermentation medium for Bacillus subtilis to produce nattokinase. The highest viability of nattokinase can be achieved by replacing the nitrogen source in the original medium with TPW. It is shown that organic nitrogen is significantly more effective than inorganic nitrogen in promoting the synthesis of nattokinase. To satisfy the cell growth requirements, complex nitrogen sources have to be broken down by increasing the expression of proteases such as nattokinase by Bacillus subtilis [16]. In addition to the high concentration of COD and BOD (Table 5), the main components of TPW include proteins, peptides, and amino acids too. The primary amino 

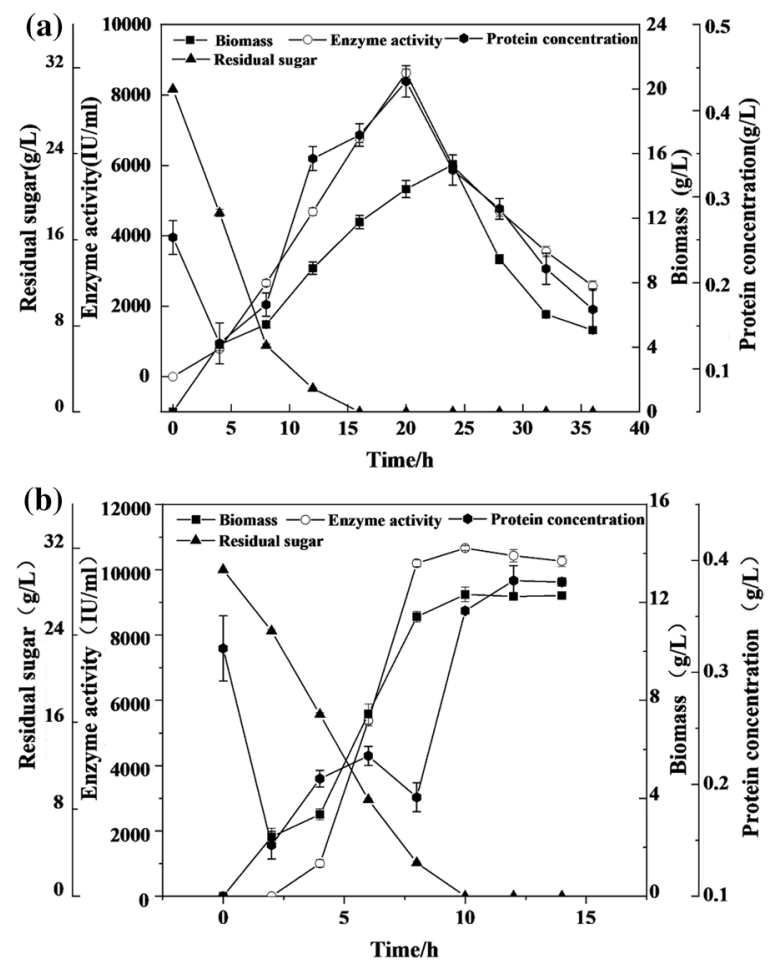

Fig. 5 Batch fermentation in $7 \mathrm{~L}$ and $100 \mathrm{~L}$ bioreactors

acid components of TPW, i.e., Asp, Ser, Gly, Arg, Lys, Glu, His, and Leu, were added to a blank medium separately, and the results show that the addition of certain low amino acids concentrations (Leu, Arg, Asp, Gly) are effective in enhancing the activity of nattokinase.

In contrast, as the concentration of amino acids added in the system increases, the other three amino acid concentrations (Arg, Asp, Gly), except Leu, exhibt detrimental effects on the synthesis of nattokinase. Thus, it can be hypothesized that the synthesis of nattokinase and enzyme activity can be inhibited by the presence of high amino acid concentration. Due to the high amino acid concentrations in TPW, the role of amino acid-induced enzyme production in TPW can be excluded. This standpoint is consistent with other researchers, such as $\mathrm{Li}-\mathrm{Li}$ Man, who suggested that the peptide component in the soybean peptone was a critical factor in facilitating the synthesis of nattokinase rather than amino acids [17].

To further investigate the role of peptides, soymilk was treated with acid hydrolysis during ethanol precipitation. This process can remove the soymilk proteins after the hydrolysis, which leaves behind the peptide fraction. $2 \%$ soymilk hydrolysate and $2 \%$ soymilk protein were added to the blank medium, and the results are shown in Fig. 2 b. It can be observed that the addition of $2 \%$ soymilk hydrolysate is effective in promoting the production of nattokinase. Such a result indicates that the hydrolyzed peptide fraction is able to induce the production of nattokinase. TPW is the wastewater produced when soymilk is brined and extruded to form tofu. As the result of this physical action, free polypeptides can be generated, and this may be the key reason for the enhanced production of nattokinase from TPW.

According to the previous reports, glucose, $\mathrm{Ca}^{2+}$, and $\mathrm{Mg}^{2+}$ have been identified as key factors that can affect the production of nattokinase by Bacillus subtilis $[18,19]$. Thus, it is necessary to optimize the concentrations of the key components in the TPW medium. BBD experiments

Table 5 Chemical parameters of TPW

\begin{tabular}{lc}
\hline Parameter & Value \\
\hline $\mathrm{pH}$ & $5.02 \pm 0.22$ \\
Total sugar (g/L) & $4.9 \pm 1.05$ \\
Total nitrogen (g/L) & $0.91 \pm 0.36$ \\
$\mathrm{NH}_{4}{ }^{+}-\mathrm{N}(\mathrm{g} / \mathrm{L})$ & $0.026 \pm 0.005$ \\
$\mathrm{Total}_{\text {phosphorus }(\mathrm{g} / \mathrm{L})}$ & $0.127 \pm 0.017$ \\
$\mathrm{BOD}(\mathrm{g} / \mathrm{L})$ & $23.7 \pm 2.17$ \\
$\mathrm{COD}(\mathrm{g} / \mathrm{L})$ & $46 \pm 3$ \\
$\mathrm{Solid}$ content $(\mathrm{g} / \mathrm{L})$ & $0.045 \pm 0.012$ \\
$\mathrm{Cu}{ }^{2+}(\mathrm{mg} / \mathrm{L})$ & $0.73 \pm 0.18$ \\
$\mathrm{Zn}^{2+}(\mathrm{mg} / \mathrm{L})$ & $0.29 \pm 0.13$ \\
\hline
\end{tabular}

Table 4 Cost of nitrogen source and medium required for the production of nattokinase

\begin{tabular}{lllllc}
\hline Nitrogen source & Culture mode & Maximum nattokinase activity & References & $\begin{array}{l}\text { Nitrogen source cost } \\
\text { (Ton/dollar) }\end{array}$ & $\begin{array}{l}\text { Medium cost } \\
\text { (Ton/dollar) }\end{array}$ \\
\hline $10 \mathrm{~g} / \mathrm{L}$ yeast extract & $200 \mathrm{~mL}$ flask & $12.34 \mathrm{FU} / \mathrm{mL}$ & Wang et al. [29] & $30-35$ & $31.97-39.02$ \\
$13 \mathrm{~g} / \mathrm{L}$ soy peptone & $250 \mathrm{~mL}$ flask & $31.06 \pm 0.297 \mathrm{FU} / \mathrm{mL}$ & Nguyen [30] & $52.22-63.41$ & $64.6-81.25$ \\
$20 \mathrm{~g} / \mathrm{L}$ soy peptone & $100 \mathrm{~mL}$ flask & $871.56 \mathrm{IU} / \mathrm{mL}$ & Zhou et al. [31] & $80.33-97.55$ & $90.71-117.13$ \\
$10 \mathrm{~g} / \mathrm{L}$ peptone $+5 \mathrm{~g} / \mathrm{L}$ & $250 \mathrm{~mL}$ flask & $3284 \pm 58 \mathrm{IU} / \mathrm{mL}$ & Ju et al. [32] & $55.16-66.27$ & $78.10-89.21$ \\
yeast extract & & & Deepak et al. [33] & $275.31-314.64$ & $281.8-326.17$ \\
$55 \mathrm{~g} / \mathrm{L}$ peptone & $250 \mathrm{~mL}$ flask & $3194.25 \mathrm{U} / \mathrm{mL}$ & In study & - & \\
$100 \%$ TPW & $500-\mathrm{mL}$ flask & $7708.89 \pm 133.67 \mathrm{IU} / \mathrm{mL}$ & & & $19-37.92$ \\
\hline
\end{tabular}


were conducted to optimize the concentrations of the four key components, i.e., glucose, TPW, $\mathrm{Ca}^{2+}$, and $\mathrm{Mg}^{2+}$, and the results show that the optimal combination consists of $30.868 \mathrm{~g} / \mathrm{L}$ glucose, $93.669 \% \mathrm{TPW}, 1.129 \mathrm{~g} / \mathrm{L}$ $\mathrm{MgSO}_{4} \cdot 7 \mathrm{H}_{2} \mathrm{O}$, and $0.791 \mathrm{~g} / \mathrm{L} \mathrm{CaCl}$. Based on this optimal combination, the nattokinase activity is able to attain $7209.15 \pm 195.46 \mathrm{IU} / \mathrm{mL}$. According to the ANOVA results, glucose and TPW exert significant effects on the production of nattokinase. Other than the optimization of the components in the medium, culture conditions such as temperature, initial $\mathrm{pH}$, loading volume, and speed can also influence the production of enzyme, and these conditions have to be optimized as well. Based on the results, an initial $\mathrm{pH}$ range of $7-7.5$ is the most favorable for the production of nattokinase. The transportation of substances across the cell membrane of the microbe and various enzymatic reactions can be affected as the initial $\mathrm{pH}$ varies [20]. At the approporiate $\mathrm{pH}$ range, the relative metabolic efficiency of microorganisms can be enhanced. The growth of Bacillus subtilis is partially coupled with the production of nattokinase, and therefore achieving an efficient metabolic efficiency can promote both the growth of organism and enzyme production capacity. It is worth noting that shaker speed and liquid medium volume correlate with the dissolved oxygen (DO) concentration in the fermentation broth. Based on the result, the highest nattokinase activity is obtained with a shaker speed of $200 \mathrm{rpm}$ or a liquid medium volume of $70 \mathrm{~mL}$. An moderate oxygen level is necessary as high or low dissolved oxygen levels are not conducive to cell growth and enzyme production. This is because insufficient dissolved oxygen content in the fermentation medium can retard the growth of Bacillus subtilis, and this is detrimental towards the production of enzyme. On the other hand, too much dissolved oxygen can lead to oxygen toxicity in the bacterium, which also negatively affects enzyme production [21]. The most suitable enzyme production temperature for Bacillus subtilis is $37^{\circ} \mathrm{C}$. It can be observed that the enzyme activity decreases when the temperature deviates from $37^{\circ} \mathrm{C}$. As such, based on this result, it can be concluded that temperature can correlate with the catalytic activity of various enzymes in the microorganisms. The inhibition or inactivation of various enzymatic reactions in the microorganisms at unsuitable temperatures can affect their growth and the synthesis of nattokinase by secretion [22]. According to the result obtained from the scale-up fermentation experiments from 7 to $100 \mathrm{~L}$ bioreactors, there is a reduction in the fermentation cycle from 20 to $10 \mathrm{~h}$, with a $23.5 \%$ increase in the nattokinase activity. When compared to the experiment based on shake flask, there is an increase in the enzyme production capacity of Bacillus subtilis in both scale-up fermentation experiments. Such a result may be due to the different forms of agitation used in the process and increased dissolved oxygen content in the fermentation broth. Thus, according to the collective results, the concept of using TPW at an industrial scale to replace the nitrogen source in the original culture medium for the production of nattokinase is highly feasible.

\section{Conclusions}

Cardiovascular-related disease possesses significant threats to human health. Nattokinase has been proposed in the prevention and treatment of cardiovascular-related diseases such as hypertension due to its excellent fibrinolytic activity. To achieve a broader commercial application, it is highly necessary to produce nattokinase with high enzyme activity a low-cost. This study has confirmed the feasibility of producing nattokinase from the use of active fraction in tofu processing wastewater under the action of Bacillus subtilis. According to the results, only glucose, calcium, and magnesium ions were required in TPW for the production of nattokinase via fermentation. It was shown that Bacillus subtilis could utilize TPW medium better than soy peptone medium to produce the enzyme. After analyzing the factors that could induce the production of enzyme in TPW, it was noted that a certain peptide fraction from the hydrolysis of soy protein could contribute to the enhancement of nattokinase activity. Based on this foundation, the conditions of the enzyme production using Bacillus subtilis were optimized, and improved fermentation enzyme production activity was recorded. Furthermore, the feasibility of large-scale conversion of TPW for the production of nattokinase was demonstrated by conducting pilot tests in $7 \mathrm{~L}$ and $100 \mathrm{~L}$ bioreactors.

\section{Materials and methods \\ Strain and material}

Nattokinase-producing bacterium, i.e., Bacillus subtilis 13932 (Conservation No. CGMCC13932), was isolated from Chinese tempeh, and then it was subsequently conserved in the China General Microbiological Culture Collection Center. Fibrinogen $(130 \mathrm{mg} /$ bottle), thrombin (190 bp/bottle), and urokinase (1280 IU/bottle) standards were purchased from Beijing Zhongke Quality Control Biotechnology Co., Ltd. Experimental tofu processing wastewater and soy milk was provided by Nanjing Dou Guo Guo Food Technology Co. Other analytical reagents were purchased from Nanjing WANQING chemical Glassware and Instrument Co., Ltd.

\section{Basic culture media}

$100 \mathrm{~mL}$ LB liquid medium in a $500 \mathrm{~mL}$ Erlenmeyer flask was used as the seed solution, and it was incubated for $16 \mathrm{~h}$ before transferring $2 \%$ bacterial seed liquid to 
the tofu processing wastewater fermentation medium. The composition of blank medium was $20 \mathrm{~g} / \mathrm{L}$ glucose, $20 \mathrm{~g} / \mathrm{L}$ soybean peptone, $0.2 \mathrm{~g} / \mathrm{L} \mathrm{CaCl}_{2}$, and $0.6 \mathrm{~g} / \mathrm{L}$ $\mathrm{MgSO}_{4} \cdot 7 \mathrm{H}_{2} \mathrm{O}$, with a $\mathrm{pH}$ of 7.0 . Tofu processing wastewater replaces soy peptone as a nitrogen source, and henceforth referred as TPW culture medium.

\section{Pre-treatment of soy milk}

The $\mathrm{pH}$ of the soy milk was adjusted to 5.5 by adding hydrochloric acid. After which, the mixture was stirred for $50 \mathrm{~min}$ at $50{ }^{\circ} \mathrm{C}$. Subsequently, the mixture was centrifuged at $4000 \mathrm{rpm}$ for $30 \mathrm{~min}$ to collect the supernatant (denoted as supernatant 1) for further experiment. $70 \%$ ethanol was then added to supernatant 1 and it was stirred for $30 \mathrm{~min}$ at $55^{\circ} \mathrm{C}$. Finally, the mixture was centrifuged to obtain supernatant 2 for further experiment [23].

\section{Tofu processing wastewater as an alternative nitrogen source for the production of nattokinase}

A 3-level Box-Behnken Design (BBD) with 4-factor was conducted to optimize the effects of glucose, TPW, $\mathrm{CaCl}_{2}$, and $\mathrm{MgSO} 4 \cdot 7 \mathrm{H}_{2} \mathrm{O}$ on the production of nattokinase. The experimental design is shown in Table 2.

All experiments were repeated 3 times in conical flasks (500 mL) containing $100 \mathrm{~mL}$ liquid medium. Fermentation was performed at $33{ }^{\circ} \mathrm{C}$, initial $\mathrm{pH}$ of 7.0-7.2, and $200 \mathrm{rpm}$ for $60 \mathrm{~h}$. At the end of the fermentation, nattokinase activity was recorded.

\section{Optimization of the fermentation conditions}

Single-factor experiments were designed to optimize the culture conditions based on the optimized media. Fermentation was conducted at $33{ }^{\circ} \mathrm{C}$ and $100 \mathrm{~mL} / 500 \mathrm{~mL}$ liquid medium volume for $60 \mathrm{~h}$. The effects of the shaker speed $(80,120,160,200$, and $240 \mathrm{rpm}$ ) and initial $\mathrm{pH}$ $(5.5,6.0,6.5,7.0,7.5$, and 8.0$)$ on the production of nattokinase by Bacillus subtilis were assessed. The effects of temperature $\left(29,33,37,41\right.$, and $\left.45^{\circ} \mathrm{C}\right)$ and volume of liquid medium $(30,70,100,130$, and $160 \mathrm{~mL})$ on the viability of nattokinase were assessed at an initial $\mathrm{pH}$ of 7.0 and a shaker speed of $200 \mathrm{rpm}$.

\section{Batch fermentation}

Pilot experiments involving a $7 \mathrm{~L}$ bioreactor were performed with a liquid medium volume of $3 \mathrm{~L}$, a ventilation ratio of $1.1 \mathrm{vvm}$, and a speed of $300 \mathrm{rpm}$ (To meet the demand for dissolved oxygen, the stirring speed in the $7 \mathrm{~L}$ bioreactor was increased to $300 \mathrm{rpm}$ ). Pilot experiments involving a $100 \mathrm{~L}$ bioreactor were performed with a liquid medium volume of $60 \mathrm{~L}$, a ventilation ratio of $1.1 \mathrm{vvm}$, and a speed of $300 \mathrm{rpm}$ (To meet the demand for dissolved oxygen, the stirring speed in the $100 \mathrm{~L}$ bioreactor was increased to $300 \mathrm{rpm}$ ). The incubation temperature and initial $\mathrm{pH}$ used in all cases were $37{ }^{\circ} \mathrm{C}$ and $7-7.5$, respectively.

\section{Analysis methods Biomass}

The fermentation broth was centrifuged at 12,000 rpm for $15 \mathrm{~min}$. After which, the collected residue was washed 3 times with saline $(0.9 \% \mathrm{NaCl})$, and then it was dried in a vacuum drying oven at $55{ }^{\circ} \mathrm{C}$ until a constant weight was achieved.

\section{TPW biochemical fraction analysis}

The contents of COD, ammonia nitrogen, total phosphorus, $\mathrm{Cu}^{2+}$, and $\mathrm{Zn}^{2+}$ in the wastewater were analyzed using a multi-parameter water quality tester 5B-3BW (Beijing Lianhua Technology Development Co., Ltd.) $[24,25]$. The contents of total nitrogen in the wastewater were analyzed using Kjeldahl (FOSS ScinoCo.,Ltd.). The $\mathrm{pH}$ of TPW was measured using a $\mathrm{pH}$ meter (METTLER TOLEDO), and the BOD was measured using a biochemical oxygen demand (BOD5) tester (Beijing Lianhua Technology Development Co.). Amino acids were determined by the pre-column derivatization with phenyl isothiocyanate [26].

\section{Enzyme activity determination method}

Nattokinase activity was determined by employing the fibrin plate method $[27,28]$. Urokinase was used as a standard. $39 \mathrm{~mL}$ of $1.5 \%(\mathrm{w} / \mathrm{v})$ agarose dissolved in a phosphate-sodium chloride mixture (1:17 mixture consisting of phosphate buffer with $\mathrm{pH}$ of 7.8 and saline) was mixed with $39 \mathrm{~mL}$ of $1.5 \mathrm{mg} / \mathrm{mL}$ fibrinogen solution, and $3 \mathrm{~mL}$ of thrombin $(1 \mathrm{bp} / \mathrm{mL})$ solution was added and then it was mixed rapidly. $20 \mathrm{~mL}$ of the mixture was added to a $90 \mathrm{~mm}$ cell culture plate and it was left to solidify at room temperature for $1 \mathrm{~h}$. The fermentation broth was centrifuged at 12,000 rpm for $5 \mathrm{~min}$ and then it was diluted 20 -fold with saline $(0.9 \% \mathrm{NaCl})$. The wells were punched on a fibrin plate, and $10 \mu \mathrm{L}$ of enzyme solution was added to the wells. The system was incubated at $37^{\circ} \mathrm{C}$ for $18 \mathrm{~h}$. The vertical diameters of the fibrinolytic circles were determined by using vernier calipers. The enzymatic activity of the urokinase standard was used as the vertical coordinate, while the product of the two vertical diameters was used as the horizontal coordinate. The nattokinase activity was calculated based on the urokinase standard curve.

\section{Abbreviations}

TPW: Tofu process wastewater; BBD: Box-Behnken design; DO: Dissolved oxygen; vvm: Air volume/culture volume/min; HPLC: High-performance liquid chromatography; Asp: Aspartic acid; Ser: Serine; Gly: Glycine; Arg: Arginine; Lys: 
Lysine; Glu: Glutamic acid; His: Histidine; Leu: Leucine; COD: Chemical oxygen demand; BOD: Biochemical oxygen demand; PITC: Phenyl isothiocyanate; CGMCC: China general microorganism culture collection.

\section{Supplementary Information}

The online version contains supplementary material available at https://doi. org/10.1186/s12896-021-00719-1.

Additional file 1: Table S1. Market prices of various carbon and nitrogen sources on Alibaba.com in March. Figure S1. High-performance liquid chromatography diagram of amino acid standard.

\section{Acknowledgements}

The authors thank Associate Professor Li Ganlu of the School of Biological and Pharmaceutical Engineering, Nanjing Tech University for providing the pilot fermentation site. The National Biochemical Technology Research Center of Nanjing Tech University for providing technical support for the quantitative determination of amino acids in tofu processing wastewater.

\section{Authors' contributions}

TL: Investigation, Methodology, Data curation, Writing original an draft. CYZ: Investigation, Validation. GGG: Investigation, Methodology, Data curation. ZXL: Investigation, Validation. NH: resource, Project administration. PKO: review and editing. All the authors read and approved the manuscript for submission.

\section{Funding}

This study was supported by the National Key Research and Development Program of China (No. 2019YFA0905003), the Key Research and Development Program of Jiangsu Province (No. BE2020346), the Six Talent Peaks Project in Jiangsu Province (No. 2019-NY-058), the Jiangsu Province Agricultural Independent Innovation Project (No. SCX (19)3086), and the Project of Priority Academic Program Development of Jiangsu Higher Education Institutions (PAPD).

\section{Availability of data and materials}

All data generated or analyzed during this study are included in this published article and its Additional file 1.

\section{Declarations}

Ethics approval and consent to participate Not applicable.

\section{Consent for publication}

Not applicable.

\section{Competing interests}

The authors declare that they have no competing interests.

Received: 23 March 2021 Accepted: 29 September 2021

Published online: 07 October 2021

\section{References}

1. Cai D, Zhu C, Chen S. Microbial production of nattokinase: current progress, challenge and prospect. World J Microbiol Biotechnol. 2017;33:84

2. Weng Y, Yao J, Sparks S, Wang KY. Nattokinase: an oral antithrombotic agent for the prevention of cardiovascular disease. Int J Mol Sci. 2017; 18:523.

3. Dabbagh F, Negahdaripour M, Berenjian A, Behfar A, Mohammadi F, Zamani M, Irajie C, Ghasemi Y. Nattokinase: production and application. Appl Microbiol Biotechnol. 2014;98:9199-206.

4. Wei X, Zhou Y, Chen J, Cai D, Wang D, Qi G, Chen S. Efficient expression of nattokinase in Bacillus licheniformis: host strain construction and signal peptide optimization. J Ind Microbiol Biotechnol. 2015;42:287-95.
5. Wang SL, Chen HJ, Liang TW, Lin YD. A novel nattokinase produced by Pseudomonas sp. TKU015 using shrimp shells as substrate. Process Biochem. 2009:44:70-6.

6. Wang SL, Liang TW, Yen YH. Bioconversion of chitin-containing wastes for the production of enzymes and bioactive materials. Carbohydr Polym. 2011;84:732-42.

7. Sahoo A, Mahanty B, Daverey A, Dutta K. Nattokinase production from Bacillus subtilis using cheese whey: effect of nitrogen supplementation and dynamic modelling. J Water Process Eng. 2020;38:101533.

8. Pan S, Chen G, Zeng J, Cao X, Zheng X, Zeng W, Liang Z. Fibrinolytic enzyme production from low-cost substrates by marine Bacillus subtilis: process optimization and kinetic modeling. Biochem Eng J. 2019;141:268-77.

9. Wang H, Sun X, Wang L, Wu H, Zhao G, Liu H, Wang P, Zheng Z. Coproduction of menaquinone-7 and nattokinase by Bacillus subtilis using soybean curd residue as a renewable substrate combined with a dissolved oxygen control strategy. Ann Microbiol. 2018;68:655-65.

10. Choi IS, Kim YG, Jung JK, Bae H-J. Soybean waste (okara) as a valorization biomass for the bioethanol production. Energy. 2015;93:1742-7.

11. $\mathrm{Yu} \mathrm{HQ}, \mathrm{Hu} \mathrm{ZH}, \mathrm{Hong} T Q, \mathrm{Gu} G W$. Performance of an anaerobic filter treating soybean processing wastewater with and without effluent recycle. Process Biochem. 2002;38:507-13.

12. Lay CH, Sen B, Huang SC, Chen CC, Lin CY. Sustainable bioenergy production from tofu-processing wastewater by anaerobic hydrogen fermentation for onsite energy recovery. Renew Energy. 2013;58:60-7.

13. Chen Y, Zhang F, Wang T, Shen N, Yu ZW, Zeng RJ. Hydraulic retention time affects stable acetate production from tofu processing wastewater in extreme-thermophilic $\left(70^{\circ} \mathrm{C}\right)$ mixed culture fermentation. Bioresour Technol. 2016;216:722-8.

14. Wang SK, Wang X, Miao J, Tian YT. Tofu whey wastewater is a promising basal medium for microalgae culture. Bioresour Technol. 2018:253:79-84.

15. Hsia C-H, Shen M-C, Lin J-S, Wen Y-K, Hwang K-L, Cham T-M, Yang N-C. Nattokinase decreases plasma levels of fibrinogen, factor VII, and factor VIII in human subjects. Nutr Res. 2009;29:190-6.

16. Chang CT, Wang PM, Hung YF, Chung YC. Purification and biochemical properties of a fibrinolytic enzyme from Bacillus subtilis-fermented red bean. Food Chem. 2012;133:1611-7.

17. Man LL, Xiang DJ, Zhang CL. Strain screening from traditional fermented soybean foods and induction of nattokinase production in Bacillus subtilis MX-6. Probiotics Antimicrob Proteins. 2019;11:283-94.

18. Ku TW, Tsai RL, Pan TM. A simple and cost-saving approach to optimize the production of subtilisin NAT by submerged cultivation of Bacillus subtilis Natto. J Agric Food Chem. 2009;57:292-6.

19. Ngo Thi Tuong C. Optimization of the medium components for recombinant nattokinase production by Bacillus Subtilis BD170. VNU J Sci Earth Environ Sci. 2017;33:129-35.

20. Khursade PS, Galande SH, Shiva Krishna P, Prakasham RS. Stenotrophomonas maltophilia $\mathrm{Gd} 2$ : a potential and novel isolate for fibrinolytic enzyme production. Saudi J Biol Sci. 2019;26:1567-75.

21. Wu R, Chen G, Pan S, Zeng J, Liang Z. Cost-effective fibrinolytic enzyme production by Bacillus subtilis WR350 using medium supplemented with corn steep powder and sucrose. Sci Rep. 2019;9:6824.

22. Sharma KM, Kumar R, Panwar S, Kumar A. Microbial alkaline proteases: optimization of production parameters and their properties. J Genet Eng Biotechnol. 2017;15:115-26.

23. Ling $X Q$, Yong $G$, Jian $L$, Yun D, Lin PH. Research of the mechanism of nattokinase biosynthesis. J Jinan Univ. 2001;22:110-4.

24. Wang X-Q, Li X, Zhou R-W, Huang J, Chen W, Wang F-P, Lu X-Y, Wen Q. Degradation of high-concentration simulated organic wastewater by DBD plasma. Water Sci Technol. 2019;80:1413-20.

25. Zhang Q, Chang C, Bai J, Fang S, Zhuang X, Yuan Z. Mutants of Scenedesmus sp. for purifying highly concentrated cellulosic ethanol wastewater and producing biomass simultaneously. J Appl Phycol. 2018;30:969-78.

26. Hao N, Yan M, Zhou H, Liu HM, Cai P, Ouyang PK. The effect of AmtR on growth and amino acids production in Corynebacterium glutamicum. Appl Biochem Microbiol. 2010;46:561-6.

27. Astrup T, Müllertz S. The fibrin plate method for estimating fibrinolytic activity. Arch Biochem Biophys. 1952;40:346-51.

28. Li C, Du Z, Qi S, Zhang X, Wang M, Zhou Y, Lu H, Gu X, Tian H. Food-grade expression of nattokinase in Lactobacillus delbrueckii subsp. bulgaricus and its thrombolytic activity in vitro. Biotechnol Lett. 2020;42:2179-87. 
29. Wang JK, Chiu HH, Hsieh CS. Optimization of the medium components by statistical experimental methods to enhance nattokinase activity. Fooyin J Health Sci. 2009;1:21-7.

30. Nguyen T. Optimization of the fermentation medium to receive the highest biomass yield by Bacillus Subtilis Natto and the initial test of nattokinase yield. IOSR J Eng. 2014;04:35-40.

31. Zhou HM, Zhang HX, Xie YH, Zhou TT, Liu H, Luo YB. Optimization of liquid fermentation conditions and encapsulation for nattokinase production. Adv Mater Res. 2013;781-784:1403-9.

32. Ju S, Cao Z, Wong C, Liu Y, Foda MF, Zhang Z, Li J. Isolation and optimal fermentation condition of the Bacillus subtilis Subsp. natto strain WTC016 for nattokinase production. Fermentation. 2019;5:92.
33. Deepak V, Kalishwaralal K, Ramkumarpandian S, Babu SV, Senthilkumar SR, Sangiliyandi G. Optimization of media composition for nattokinase production by Bacillus subtilis using response surface methodology. Bioresour Technol. 2008;99:8170-4.

\section{Publisher's Note}

Springer Nature remains neutral with regard to jurisdictional claims in published maps and institutional affiliations.
Ready to submit your research? Choose BMC and benefit from:

- fast, convenient online submission

- thorough peer review by experienced researchers in your field

- rapid publication on acceptance

- support for research data, including large and complex data types

- gold Open Access which fosters wider collaboration and increased citations

- maximum visibility for your research: over $100 \mathrm{M}$ website views per year

At BMC, research is always in progress.

Learn more biomedcentral.com/submissions 